\title{
Liquid Distribution in Trickle-Bed Reactor
}

\author{
C. Marcandelli ${ }^{1}$, A.S. Lamine' ${ }^{2}$, J.R. Bernard ${ }^{3}$ and G. Wild ${ }^{1}$ \\ 1 CNRS-ENSIC, Laboratoire des sciences du génie chimique, 1, rue Grandville, BP 451, 54001 Nancy Cedex - France \\ 2 CNRS-Université de Paris-Nord, Laboratoire d'ingénierie des matériaux et des hautes pressions, \\ avenue J.B.-Clément, 93430 Villetaneuse - France \\ 3 Elf Antar France, Centre de recherche Elf de Solaize, chemin du Canal, BP 22, 69360 Solaize - France \\ e-mail: wild@ensic.u-nancy.fr
}

\begin{abstract}
Résumé — Distribution du liquide en réacteur à lit ruisselant — Le but de cette étude est de montrer l'emploi de techniques de mesure de la qualité de distribution du liquide dans les réacteurs à lit ruisselant à l'aide de maquettes froides.

L'appareillage expérimental principal est une colonne de $0,3 \mathrm{~m}$ de diamètre, la distribution de liquide initiale étant modulée par l'utilisation de trois distributeurs différents. La qualité de la distribution a été étudiée en mettant en œuvre plusieurs techniques de mesure : perte de pression globale, DTS (distribution des temps de séjour) globale du liquide, coefficient de transfert de chaleur à des sondes, tomographie capacitive, et collecteur en bas de réacteur comprenant neuf zones d'aires égales.

La perte de charge et la rétention de liquide décroissent à maldistribution croissante ; il est cependant difficile d'obtenir une description précise de la maldistribution uniquement à partir de ces mesures. La DTS globale permet de donner une première quantification de la maldistribution du liquide. Les sondes thermiques locales donnent une indication de la vitesse locale du liquide et font apparaitre de possibles maldistributions locales du liquide (échelle du mm), même en cas de bonne distribution globale. Les résultats obtenus avec le collecteur sont représentés à l'aide d'un indice de maldistribution allant de 0 (distribution idéale) à 1 (la plus mauvaise distribution possible). On discute l'influence des conditions opératoires (vitesse de gaz et de liquide, forme des particules).

Mots-clés : réacteur à lit ruisselant, distribution du liquide, DTS (distribution des temps de séjour), collecteur de liquide, perte de charge, tomographie.
\end{abstract}

\footnotetext{
Abstract - Liquid Distribution in Trickle-Bed Reactor - The aim of this study is to develop techniques to qualify the efficiency of liquid distribution in trickle-bed reactors, using cold mockups.

The experimental setup consists mainly in a 0.3-m-ID packed-bed column with three different plates used to vary the quality of inlet liquid distribution. Liquid distribution has been qualified using several techniques: global pressure drop measurements, global RTD (Residence-Time Distribution) of the liquid, local heat transfer probes, capacitance tomography, collector at the bottom of the reactor with nine equal zones. The bed pressure drop and the overall external liquid saturation decrease when the maldistribution increases; quantitative information is however difficult to obtain this way. Global RTD of the liquid allows quantifying of the average liquid distribution in the bed. The local thermal sensors give an indication of local liquid velocity and indicate possible local maldistribution of the liquid (scale $\mathrm{mm}$ ) even when global distribution is good. Concerning the results obtained with the collector, a maldistribution index is defined, ranging from 0 (ideal distribution) to 1 (worst possible distribution), and the influence of the different operating parameters (gas and liquid velocities, particle shape) is discussed.

Keywords: trickle bed, liquid distribution, RTD (Residence-Time Distribution), liquid collector, pressure drop, tomography.
} 


\section{NOTATION}

$D_{c} \quad$ bed diameter

$d_{p} \quad$ particle diameter

$f \quad$ well irrigated zone area ratio (-)

$G \quad$ gas mass flux $\left(\mathrm{kg} \cdot \mathrm{m}^{-2} \cdot \mathrm{s}^{-1}\right)$

$H \quad$ bed height (m)

$L \quad$ liquid mass flux $\left(\mathrm{kg} \cdot \mathrm{m}^{-2} \cdot \mathrm{s}^{-1}\right)$

$M_{f} \quad$ maldistribution factor

$N \quad$ number of zones

$\Delta P \quad$ pressure drop $(\mathrm{Pa})$

$Q_{L} \quad$ liquid flow rate

$Q_{L i} \quad$ local liquid flow rate

$Q_{\text {mean }} \quad$ average liquid flow rate

$U_{G} \quad$ superficial gas liquid velocity

$U_{L} \quad$ superficial liquid velocity

$w_{L} \quad$ ratio of the liquid flow in the well irrigated flow (-)

$\beta_{L} \quad$ liquid holdup

\section{INTRODUCTION}

One of the most important applications of trickle-bed reactors is the hydrodesulfurisation (HDS) of gas oil. Gas oil feed contains usually between 1000 and 15000 ppm sulphur and sulphur specification in gas oil product is getting more and more severe: in 2005 it will reach 50 ppm in Europe; improvement of the HDS operation has therefore to be performed. Two routes for improvements are open: developing more efficient catalysts or improving the process design. The present work pertains to a major issue in the second route: the distribution of gas and liquid on the catalyst. As shown by Ross (1965) and Vergel Hernandez (1993), a bad distribution can be the cause of losses either in performance, selectivity or catalyst stability of trickle beds. The aim of this study is to develop and compare techniques to qualify the quality of liquid distribution in this type of reactor, using cold mockups to investigate the influence of operating parameters on liquid-catalyst contacting and to discuss transposition to commercial trickle-bed operation.

\section{EXPERIMENTAL PLANTS}

Three experimental setups have been used; the dimensions and packing used in the different columns are indicated in Table 1. The first two columns were situated in Nancy (France), the third one in the laboratory of Professor Mewes at Hanover University in Germany (Institut für Verfahrenstechnik). Most results presented here were obtained in Column 1; a schematic description of Setup 1 is shown in Figure 1. With glass beads or ceramic spheres, the bed porosity is, as expected, 0.41 or 0.42 . The extrudate used was industrial HDS catalyst support. The internal porosity of these particles is 0.61 , the packing is not dense and the bed porosity $(\varepsilon=0.58)$ is rather representative of bed sock loading.

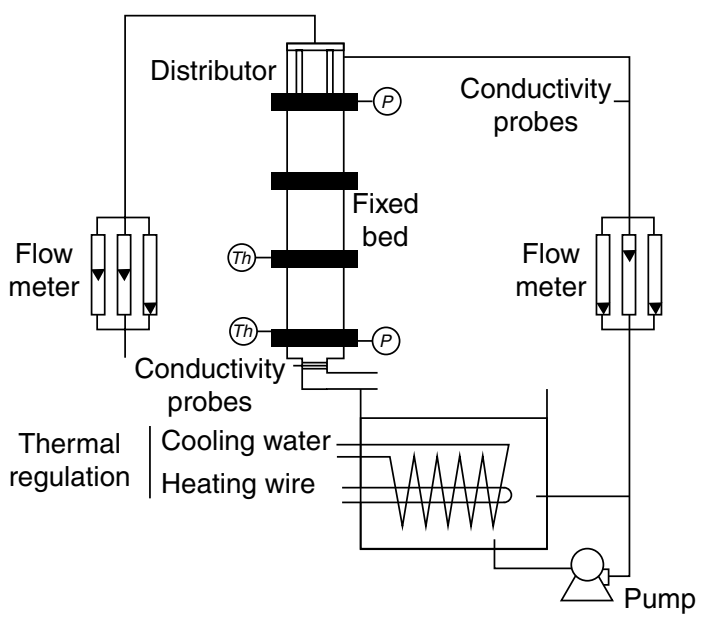

Figure 1

Schematic description of Setup 2.

TABLE 1

Characteristics of the equipment and range of velocities

\begin{tabular}{l|c|c|c}
\hline & 1 Small column & 2 Large column & 3 Tomography column \\
\hline$H(\mathrm{~m})$ & 3.3 & 1.3 & 1.3 \\
\hline$D_{c}$ & 0.1 & 0.3 & 0.12 \\
\hline$U_{L}\left(\mathrm{~m} \cdot \mathrm{s}^{-1}\right)$ & $0.004-0.02$ & $0.001-0.008$ & $0.004-0.02$ \\
\hline$U_{G}\left(\mathrm{~m} \cdot \mathrm{s}^{-1}\right)$ & $0.001-0.40$ & $0.005-0.15$ & $0.10-0.70$ \\
\hline Packings & $\begin{array}{c}\text { 2-mm glass beads } \\
\text { Polylobe extrudates }\end{array}$ & $\begin{array}{c}\text { 2-mm glass beads } \\
\text { Polylobe extrudates }\end{array}$ & 6.7-mm ceramic beads \\
\hline
\end{tabular}


The effect of the initial distribution of gas and liquid was investigated in Columns 2 and 3. Figure 2 shows the different distributors used with Column 2: with all distributors, the gas is fed through four chimneys, while the liquid is injected through a perforated plate with either 25 10-mm-ID orifices (a), two 25-mm-ID orifices (b) or one 25-mm-ID orifice (c). With Setup 3, the gas injection was homogeneous on the whole section, while the liquid was injected either on the whole section or on half of the section.

\section{MEASURING TECHNIQUES AND RESULTS}

Maldistribution can be investigated by a number of techniques, as exemplified by the list of papers shown in Table 2.

In the present work, the following techniques were employed to qualify the liquid distribution in the bed.

\subsection{Global Pressure Drop and RTD Measurements}

Piezoelectric sensors (Columns 2 and 3) measured the pressures on top of and below the bed. This technique yields global information (reactor scale).

The residence-time distribution (RTD) of the liquid was determined by measuring by conductimetry the response to a salt tracer injection at the reactor outlet. In case of nonporous particles, the RTD was interpreted using the plug flow with axial dispersion model. This yields a mean liquid holdup and a dispersion coefficient; in case of porous particles, the plug flow with exchange with stagnant liquid model was used, which also yields a good estimate of the liquid holdup (Villermaux and van Swaaij, 1969; Yang et al.,
1990). A plug flow model with diffusion in the catalyst pores was used to interpret some radioactive tracer experiments made on a commercial HDS plant.

The following qualitative rule can be established: the better the distributor, the higher the pressure drop and the liquid holdup in the bed (Trambouze et al., 1984). Comparing these global hydrodynamic characteristics obtained with two different distributors is therefore a good way to compare their performance. As an example, Figure 3 shows the pressure drop as a function of gas velocity for a given liquid velocity and packing, the only difference being the liquid distributor at the top. It clearly appears that the multiorifice distributor (a) is the most efficient one. More surprising is the fact that the single-orifice distributor (c) seems to be more efficient than the two-orifice distributor (b). This is systematically found with every technique used in this study. It can be explained because liquid is distributed axisymmetrically with the single-orifice plate, while it is distributed asymmetrically with the two-orifice distributor.

A more quantitative interpretation was done: the maldistribution was represented using the two-zone model of Kennedy and Jaffe (1986). In this model, the reactor is considered to be composed of two parallel zones which are irrigated differently. It is a two-parameter model, the parameters being the area ratio $f$ of the better irrigated zone and the liquid flow rate ratio $w_{L}$ in the better irrigated zone. Pressure drop of both zones are equalised by adjusting gas flow. Unfortunately, it is not possible to determine independently both parameters; the actual values of $f$ and $w_{L}$ obtained by fitting experimental data are, in our experience, not really significant, neither using the pressure drop, nor the RTD.

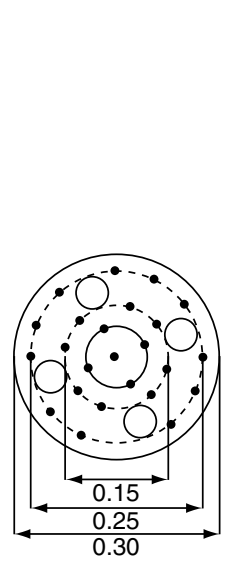

(a) Multiorifice
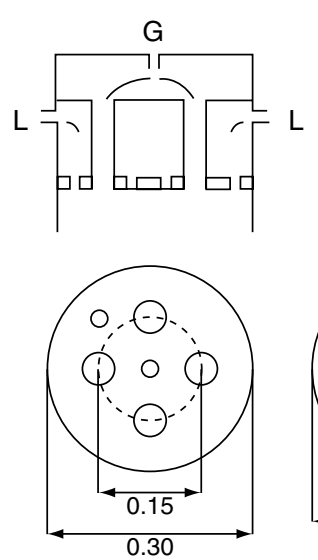

(b) Two orifices

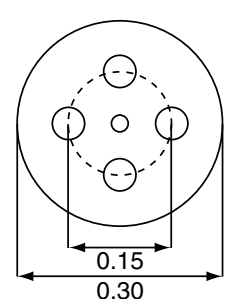

(c) Single orifice

Figure 2

Gas and liquid distributors used in Column 2.

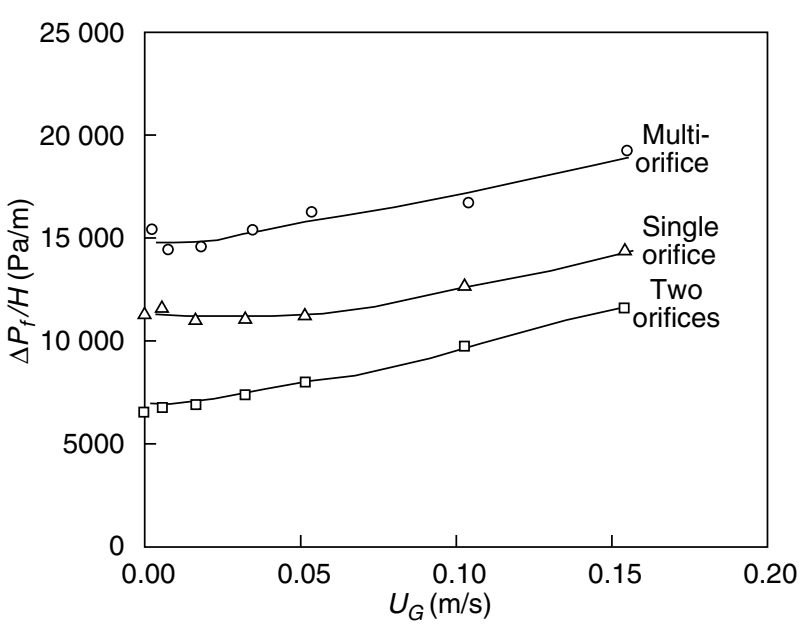

Figure 3

Influence of the distributor on the pressure drop in Column 2 provided with a $2-\mathrm{mm}$ glass beads packing $\left(U_{L}=6 \mathrm{~mm} \cdot \mathrm{s}^{-1}\right)$. 
TABLE 2

Investigations of liquid distribution in three-phase packed beds in literature

\begin{tabular}{|c|c|c|c|c|}
\hline Authors & Gas-liquid system & Geometric characteristics & Method & Range of velocities \\
\hline $\begin{array}{l}\text { Kouri and Sohlo } \\
\text { (1996) }\end{array}$ & $\begin{array}{l}\text { Countercurrent } \\
\text { Gas: air } \\
\text { Liquid: water }\end{array}$ & $\begin{array}{l}D_{c}=0.5 \mathrm{~m} ; H=0-3 \mathrm{~m} \\
d_{p}=25-50 \mathrm{~mm} ; D_{c} / d_{p}=10-20 \\
\text { Pall rings or Intalox saddles }\end{array}$ & $\begin{array}{l}\text { Annular } \\
\text { collector } \\
5 \text { zones }\end{array}$ & $\begin{array}{l}L: 2.5-10 \mathrm{~kg} \cdot \mathrm{m}^{-2} \cdot \mathrm{s}^{-1} \\
G: 0-2.7 \mathrm{~kg} \cdot \mathrm{m}^{-2} \cdot \mathrm{s}^{-1}\end{array}$ \\
\hline $\begin{array}{l}\text { Herskowitz } \\
\text { and Smith } \\
\text { (1978) }\end{array}$ & $\begin{array}{l}\text { Gas: air } \\
\text { Liquid: water + tenside }\end{array}$ & $\begin{array}{l}D_{c}=4.08-11.4 \mathrm{~cm} ; H=0-0.7 \mathrm{~m} \\
d_{p}=0.258-1.11 \mathrm{~cm} \\
D_{c} / d_{p}=4-44 \\
\text { Granules, spheres, cylinders }\end{array}$ & $\begin{array}{l}\text { Annular } \\
\text { collectors } \\
3,4 \text { or } 5 \text { zones }\end{array}$ & $\begin{array}{l}L: 1-5 \mathrm{~kg} \cdot \mathrm{m}^{-2} \cdot \mathrm{s}^{-1} \\
G: 0.001-0.05 \mathrm{~kg} \cdot \mathrm{m}^{-2} \cdot \mathrm{s}^{-1}\end{array}$ \\
\hline $\begin{array}{l}\text { Lutran et al. } \\
\text { (1991) }\end{array}$ & $\begin{array}{l}\text { Liquid only: } \\
\text { water + tenside }\end{array}$ & $\begin{array}{l}D_{c}=0.1 \mathrm{~m} ; H=0.19 \mathrm{~m} \\
d_{p}=3-6 \mathrm{~mm} ; D_{c} / d_{p}=17-33 \\
\text { Glass spheres }\end{array}$ & Tomography & $L: 3.2-9.1 \mathrm{~kg} \cdot \mathrm{m}^{-2} \cdot \mathrm{s}^{-1}$ \\
\hline $\begin{array}{l}\text { Bemer and } \\
\text { Zuiderweg } \\
(1978)\end{array}$ & $\begin{array}{l}\text { Liquide only: } \\
\text { water + alcohol }\end{array}$ & $\begin{array}{l}D_{c}=0.2 \mathrm{~m} ; H=0.05-0.3 \mathrm{~m} \\
d_{p}=0.01-0.03 \mathrm{~m} ; D_{c} / d_{p}=7-20 \\
\text { Raschig rings }\end{array}$ & $\begin{array}{l}\text { Collector } \\
177 \text { zones }\end{array}$ & $L: 0.5-8.9 \mathrm{~kg} \cdot \mathrm{m}^{-2} \cdot \mathrm{s}^{-1}$ \\
\hline $\begin{array}{l}\text { Moller et al. } \\
\text { (1996) }\end{array}$ & $\begin{array}{l}\text { Gas: air } \\
\text { Liquid: water + tenside }\end{array}$ & $\begin{array}{l}D_{c}=0.144 \mathrm{~m} ; H=0.77 \mathrm{~m} \\
d_{p}=1.6 \mathrm{~mm} \text { extrudates } \\
\text { or } 16^{*} 11 \mathrm{~mm} \text { perforated cylinders } \\
D_{c} / d_{p}=10-90\end{array}$ & Collector & $\begin{array}{l}L: 2-8 \mathrm{~kg} \cdot \mathrm{m}^{-2} \cdot \mathrm{s}^{-1} \\
G: 0-0.07 \mathrm{~kg} \cdot \mathrm{m}^{-2} \cdot \mathrm{s}^{-1}\end{array}$ \\
\hline $\begin{array}{l}\text { Borda et al. } \\
\text { (1987) }\end{array}$ & $\begin{array}{l}\text { Gas: air } \\
\text { Liquid: water + CMC }\end{array}$ & $\begin{array}{l}D_{c}=0.072 \mathrm{~m} ; H=0.85 \mathrm{~m} \\
d_{p}=4.8-7.5 \mathrm{~m} ; D_{c} / d_{p}=9.6-15 \\
\text { Cylinders or Raschig rings }\end{array}$ & $\begin{array}{l}\text { Annular } \\
\text { collectors } \\
3 \text { or } 4 \text { zones }\end{array}$ & $\begin{array}{l}L: 2-20 \mathrm{~kg} \cdot \mathrm{m}^{-2} \cdot \mathrm{s}^{-1} \\
G: 0.016-0.1 \mathrm{~kg} \cdot \mathrm{m}^{-2} \cdot \mathrm{s}^{-1}\end{array}$ \\
\hline $\begin{array}{l}\text { Sylvester } \\
\text { and Pitayagulsarn } \\
(1975)\end{array}$ & $\begin{array}{l}\text { Gas: air } \\
\text { Liquid: water }\end{array}$ & $\begin{array}{l}D_{c}=0.15 \mathrm{~m} ; H=0.15-0.91 \mathrm{~m} \\
d_{p}=0.32-0.63 \mathrm{~cm} ; D_{c} / d_{p}=24-48 \\
\text { Cylinders or Intalox saddles }\end{array}$ & $\begin{array}{l}\text { Annular } \\
\text { collector } \\
6 \text { zones }\end{array}$ & $\begin{array}{l}L: 3.6-19.7 \mathrm{~kg} \cdot \mathrm{m}^{-2} \cdot \mathrm{s}^{-1} \\
G: 0.04-0.78 \mathrm{~kg} \cdot \mathrm{m}^{-2} \cdot \mathrm{s}^{-1}\end{array}$ \\
\hline $\begin{array}{l}\text { Hoek et al. } \\
\text { (1986) }\end{array}$ & Liquid only & $\begin{array}{l}D_{c}=0.5 \mathrm{~m} ; \mathrm{H}=0-2 \mathrm{~m} \\
d_{p}=10-50 \mathrm{~mm} ; D_{c} / d_{p}=10-50 \\
\text { Raschig or Pall rings, } \\
\text { Intalox saddles }\end{array}$ & $\begin{array}{l}\text { Collector } \\
657 \text { zones and } \\
24 \text { at the wall }\end{array}$ & $L: 5-15 \mathrm{~kg} \cdot \mathrm{m}^{-2} \cdot \mathrm{s}^{-1}$ \\
\hline $\begin{array}{l}\text { Toye et al. } \\
\text { (1996) }\end{array}$ & $\begin{array}{l}\text { Gas: air } \\
\text { Liquid: water }\end{array}$ & $\begin{array}{l}D_{c}=0.6 \mathrm{~m} ; H=2 \mathrm{~m} \\
d_{p}=5 \mathrm{~cm} ; D_{c} / d_{p}=12\end{array}$ & $\begin{array}{l}\text { X-ray } \\
\text { tomography }\end{array}$ & $L: 0-10 \mathrm{~kg} \cdot \mathrm{m}^{-2} \cdot \mathrm{s}^{-1}$ \\
\hline $\begin{array}{l}\text { Reinecke } \\
\text { (1996), } \\
\text { Reinecke et al. } \\
\text { (1996a, 1996b, 1998) }\end{array}$ & $\begin{array}{l}\text { Gas: air } \\
\text { Liquid: water }\end{array}$ & $\begin{array}{l}D_{c}=0.12 \mathrm{~m} \\
\text { Spheres and monoliths }\end{array}$ & $\begin{array}{l}\text { Capacitance } \\
\text { tomography }\end{array}$ & \\
\hline $\begin{array}{l}\text { Saroha et al. } \\
\text { (1998b) }\end{array}$ & $\begin{array}{l}\text { Gas: air } \\
\text { Liquid: water, } \\
\text { water + tenside, } \\
\text { kerosene, ethylene glycol }\end{array}$ & $\begin{array}{l}D_{c}=0.152 \mathrm{~m} \\
d_{p}=1.5 \mathrm{~mm} ; D_{c} / d_{p}=100 \\
\text { Alumina extrudates }\end{array}$ & $\begin{array}{l}\text { Annular } \\
\text { collector } \\
6 \text { zones }\end{array}$ & $\begin{array}{l}L: 0.7-5 \mathrm{~kg} \cdot \mathrm{m}^{-2} \cdot \mathrm{s}^{-1} \\
G: 0-0.027 \mathrm{~kg} \cdot \mathrm{m}^{-2} \cdot \mathrm{s}^{-1}\end{array}$ \\
\hline
\end{tabular}


However, as stated by Kennedy and Jaffe (1986), this model gives a good description of data obtained in industrial plants: Figure 4 shows an RTD obtained by using radioactive tracing in a commercial HDS plant and the best fit of the two-zone model.

\subsection{Liquid Collector}

In Column 2, measurements were made with a collector placed at the bottom of the bed. This collector is shown in Figure 5. The outlet liquid flow is divided into nine equal area zones and the flow rate through each zone is determined by weighting the volume of liquid during a given time. The results obtained can be interpreted in two ways:

- looking at the flow rate map at the column outlet gives interesting information on maldistribution;

- a maldistribution factor $M_{f}$ was defined according to the following equation, where $Q_{L i}$ is the liquid flow rate through zone $i, N$ the number of zones (nine in this case) and $Q_{\text {mean }}$ the mean flow rate through all zones $\left(=Q_{L} / N\right)$ :

$$
M_{f}={\sqrt{\frac{1}{N(N-1)} \Sigma\left(\frac{Q_{L i}-Q_{\text {mean }}}{Q_{\text {mean }}}\right)^{2}}}^{2}
$$

This maldistribution factor is related (but not identical) to the one defined by Hoek et al. (1986). Its value can range from 0 (ideal distribution) to 1 (all the liquid goes through one single of the $N$ zones).

Figure 6 shows two examples of maps obtained with the best distributor (multiorifice distributor, (a)). In each sector, the ratio of the liquid flow rate through this zone to the total liquid flow rate is indicated (an ideal distribution would yield $11 \%$ in each sector). Figure 6a (no gas flow) shows clearly that, even with a good distributor, in the absence of gas flow, the liquid distribution at the outlet can be quite bad and does not necessarily present an axial symmetry. The presence of the gas flow improves distribution, but it is still not perfect.

An example of the way the maldistribution factor depends on the gas and liquid velocities is shown in Figure 7: $M_{f}$ is much larger in single-phase liquid flow than in two-phase flow and is a decreasing function of both gas and liquid velocities. The influence of the solid shape seems to be much less important. Similar results are obtained with distributors (b) and (c) (single orifice and two orifices). However, the maldistribution factor $M_{f}$ is always larger with these less efficient distributors than with distributor (a), and, at the highest gas velocities, an increase of $M_{f}$ is observed with extrudate packing at relatively high liquid velocities, as shown in Figure 8. It seems that at high gas velocities, the gas flow "hinders" spreading of the liquid.

\subsection{Capacitive Tomography}

Tomographic measuring techniques are more and more widely used in the investigation of the hydrodynamics of multiphase reactors, as shown in a number of recent review papers (Williams and Xie, 1993; Beck et al., 1997; Chaouki et al., 1997; Reinecke et al., 1998). Each of the different possible tomographic techniques has its advantages and drawbacks: the X-ray tomography used by Toye et al. (1996, 1997 ) is well suited for very small velocities, since the gasliquid repartition has to be constant during a measurement, which is quite slow. In the present work, the capacitive tomography developed by the team of Hanover was used (Reinecke, 1996; Reinecke and Mewes, 1996a, 1996b; Reinecke et al., 1998). Details of the measuring equipment, involved electronics and reconstruction algorithms may be

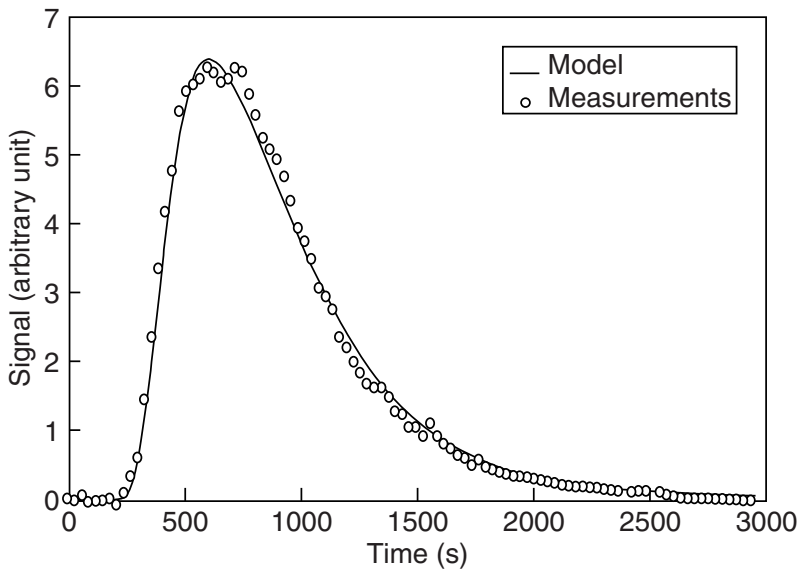

Figure 4

RTD of liquid in a commercial plant $\left(U_{L}=4 \mathrm{~mm} \cdot \mathrm{s}^{-1}\right.$; $\left.U_{G}=0.111 \mathrm{~m} \cdot \mathrm{s}^{-1} ; f=0.55 ; w_{L}=0.46\right)$.

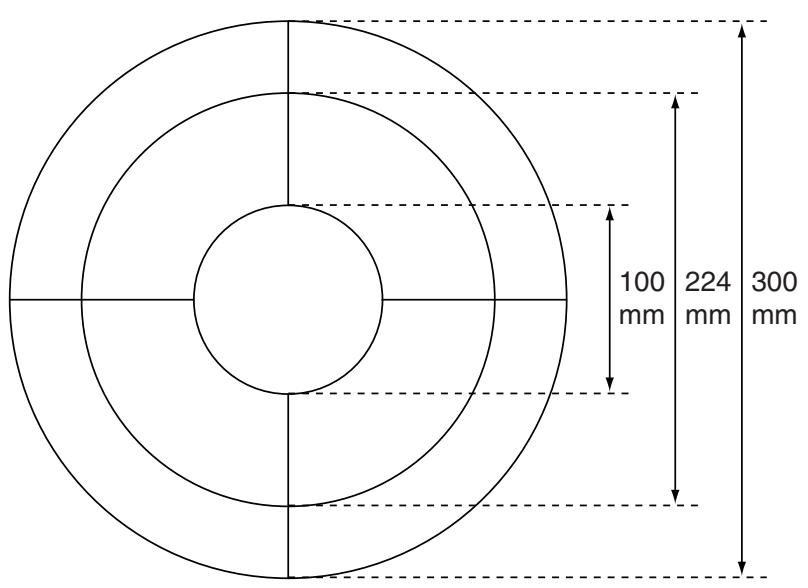

Figure 5

Collector placed at the bottom of Column 2. 

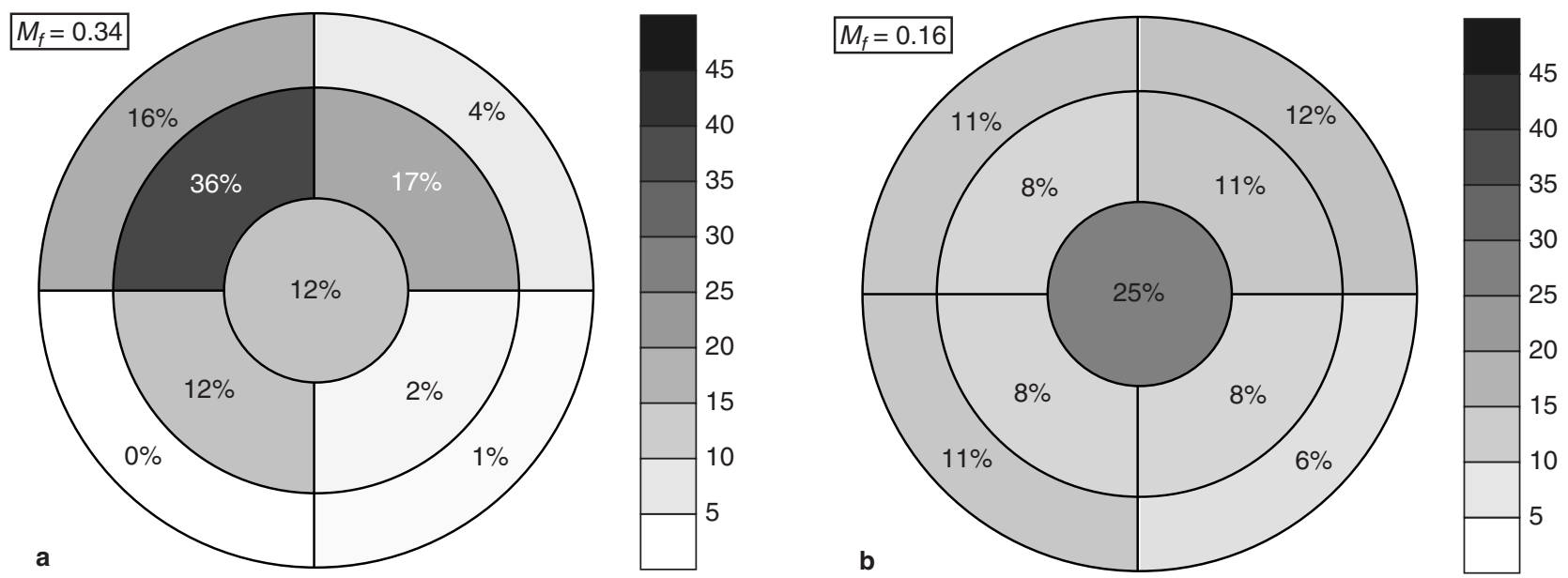

Figure 6

Flow maps obtained with the collector at the bottom of Column 2. (a) 2-mm glass beads; $U_{L}=8 \mathrm{~mm} \cdot \mathrm{s}^{-1} ; U_{G}=0$; (b) 2-mm glass beads; $U_{L}=3 \mathrm{~mm} \cdot \mathrm{s}^{-1} ; U_{G}=0.05 \mathrm{~m} \cdot \mathrm{s}^{-1}$.

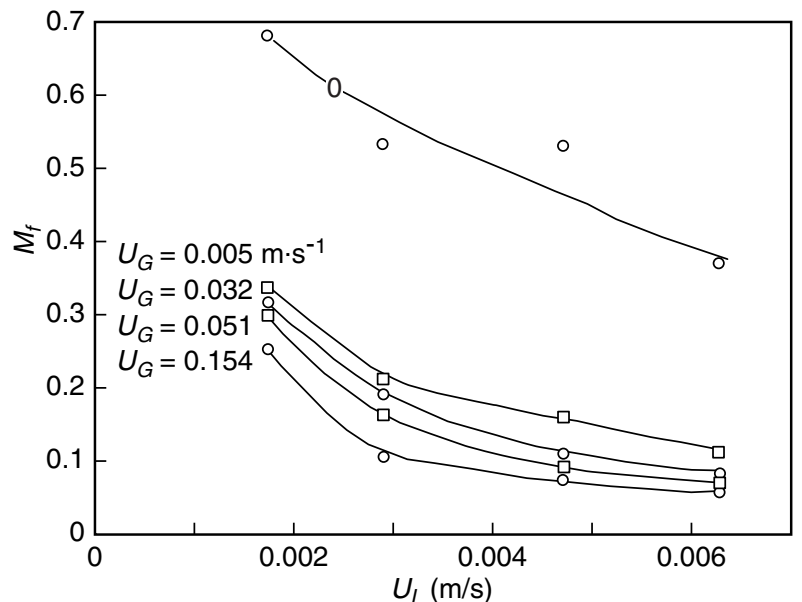

Figure 7

Maldistribution index $M_{f}$ as a function of the gas and liquid velocities (Column 2; distributor (a); 2-mm glass beads).

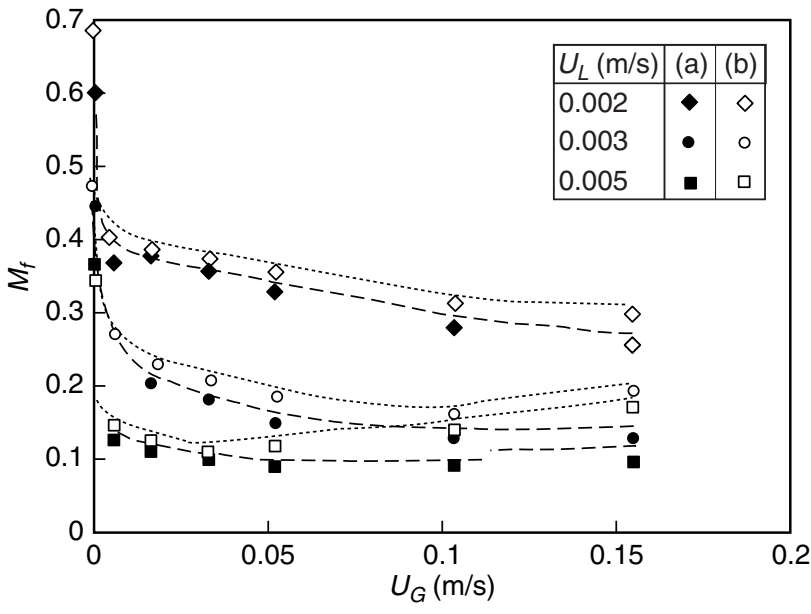

Figure 8

Maldistribution index as a function of the gas and liquid velocities: comparison of distributors (a) (multiorifice) and (b) (two orifices) (Column 2, polylobe extrudates). found in the mentioned papers. The main advantage of this technique is that it is very fast (response time of the order of magnitude of a few milliseconds). Its drawback is a low spatial resolution (approximately $25 \mathrm{~mm}$ here). Since the capacity signals depend on the distribution of the liquid in the whole bed section, the reconstruction of the liquid distribution is not easy and the actual values of the local liquid holdup should be treated with care. Another drawback is that with porous catalyst support particles, the difference between a column filled with particles and water and one filled with wet particles and air proved to be negligible and measurements could only be made with ceramic spheres.
The results were all obtained in Column 3 with the large ceramic particles. While the collector yields distributions of the liquid flow rate at the bottom of the bed, tomography yields the distribution of the liquid holdup at the level of the distributor $(0.6 \mathrm{~m}$, i.e. five diameters from the distributor). As with the collector, the tomography measurements show that even with a good initial distribution, distribution of the liquid may be inhomogeneous, especially in the absence of gas flow. Increasing the gas and liquid flow rates usually leads to a better homogeneity, but an initial maldistribution is still visible after five column diameters, as can be seen in Figure 9, which represents the lines of equal liquid holdup in 

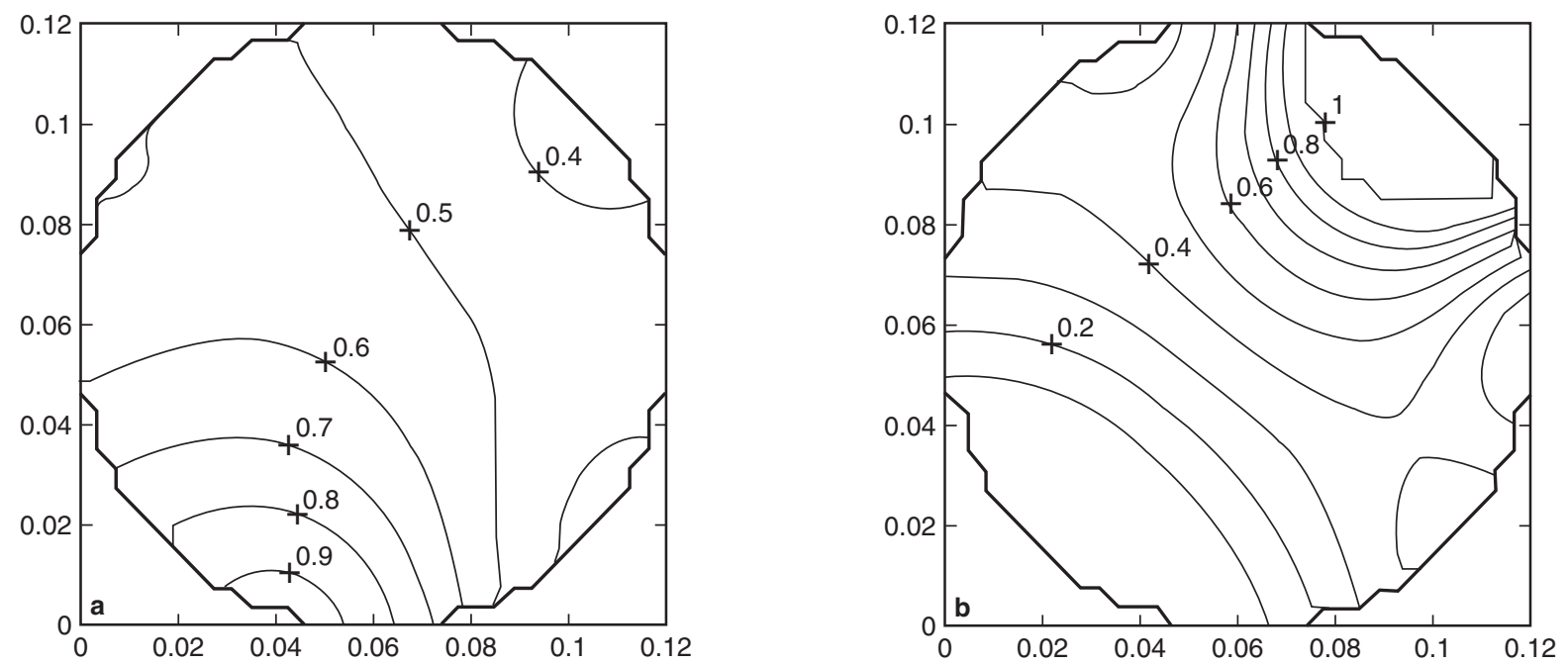

Figure 9

Iso-liquid saturation curves obtained by capacitive tomography (Column 3, ceramic particles). (a) Good initial distribution; $U_{L}=4 \mathrm{~mm} \cdot \mathrm{s}^{-1}$; $U_{G}=0.14 \mathrm{~m} \cdot \mathrm{s}^{-1} ;$ (b) Liquid fed only on half of the column; $U_{L}=4 \mathrm{~mm} \cdot \mathrm{s}^{-1} ; U_{G}=0.13 \mathrm{~m} \cdot \mathrm{s}^{-1}$.

a section of the column. In Figure 9a (good initial distribution), the liquid saturation $\beta$ takes values ranging from 0.4 to 0.9 ; in Figure $9 \mathrm{~b}$ (liquid fed only on half the section of the column), it takes values ranging from below 0.1 to 1 .

We noticed that the maldistribution index for liquid holdup is very much deteriorated by the suppression of the gas flow. This is not the case of the maldistribution index for liquid retention measured either by tomography or by RTD. This suggests that liquid retention is not a good indicator of phase distribution in a chemical reactor where local space velocity is the key parameter.

\subsection{Heat Transfer Sensors}

Small heat transfer probes (diameter approximately $2 \mathrm{~mm}$ ) have been used to investigate particle-liquid heat transfer in Column 1 (Marcandelli et al., 1999). A schematic representation of the heat transfer probe is given in Figure 10. The results obtained in the work mentioned showed that, while the heat transfer coefficient presented a strong variation, its mean value was proportional to the linear velocity of the liquid (Fig. 11). It is therefore a fair assumption that the local heat transfer coefficient to the probe depends on the local (scale $2 \mathrm{~mm}$ ) liquid velocity.

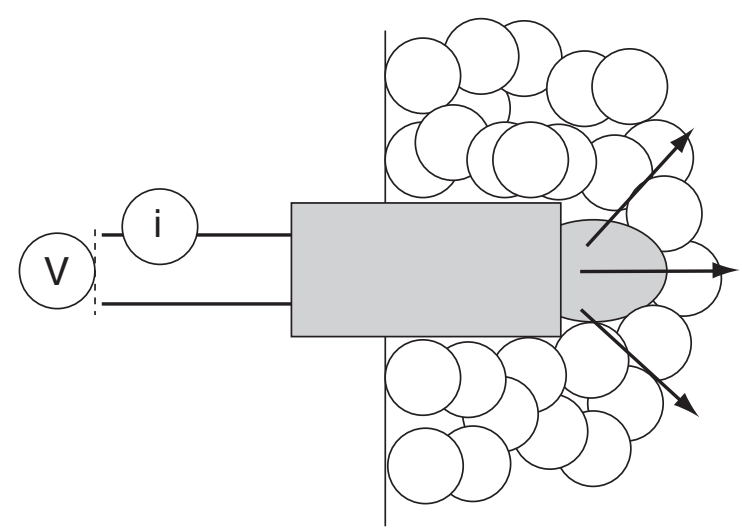

Figure 10

Schematic representation of the heat transfer probes.

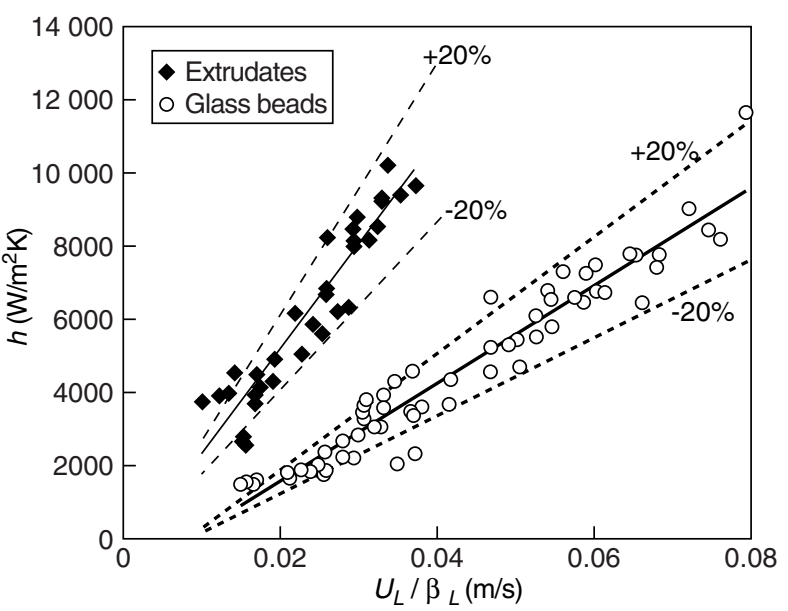

Figure 11

Mean value of the particle heat transfer coefficient as a function of linear liquid velocity (Column 1). 

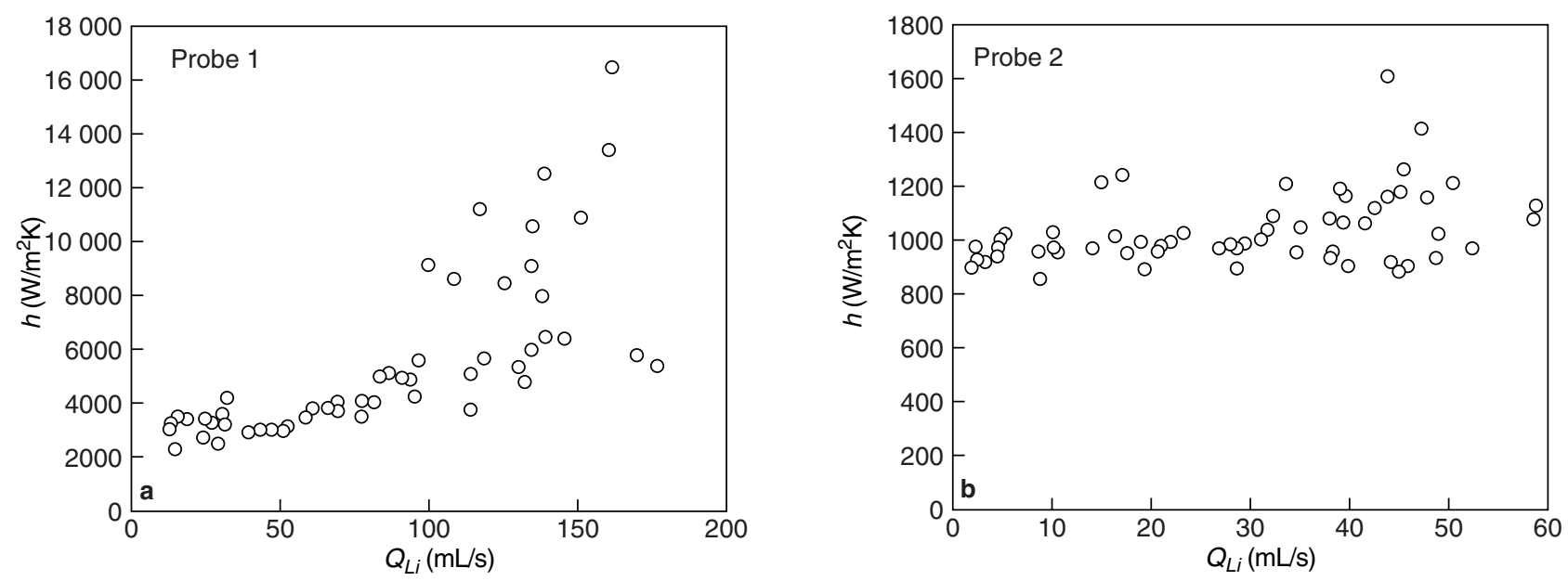

Figure 12

Heat transfer coefficients obtained with two probes in Column 2 (2-mm glass beads).

The same heat transfer probes were inserted in Column 2 in the bed not far from the collector. Figure 12 shows the heat transfer coefficients measured with two probes at different locations, as a function of the mean liquid velocity in the sector where the probe is located. While the first probe (Fig. 12a) yields values which are typical of a probe in a liquid flow and the heat transfer coefficient globally increases with increasing liquid velocity, the same is not true for the second probe (Fig. 12b). Here, most results are in the range of $1000 \mathrm{~W} \cdot \mathrm{m}^{-2} \cdot \mathrm{s}^{-1}$ or less, which corresponds to the order of magnitude obtained in single-phase gas flow through the bed.

These results indicate the presence of maldistribution on a level larger than a particle size: Vergel Hernandez (1993) had already observed similar dry zones using a colour tracer technique.

\section{DISCUSSION AND CONCLUSIONS}

It is clear from the results presented here that there cannot be a unique technique to investigate maldistribution in tricklebed reactors: beside global maldistributions on the column scale, which can be detected relatively easily, segregation may also happen at smaller scales. Figure 13 gives an overview on the different techniques used in this work and on the scale at which liquid segregation can be investigated with these techniques. While large-scale maldistribution may be due either to a distributor not well working or to inhomogeneities in the packing, the origin of small-scale segregation is less well known, although the consequences on selectivity and conversion can be quite dramatic (Vergel Hernandez, 1993; Vergel et al., 1995).

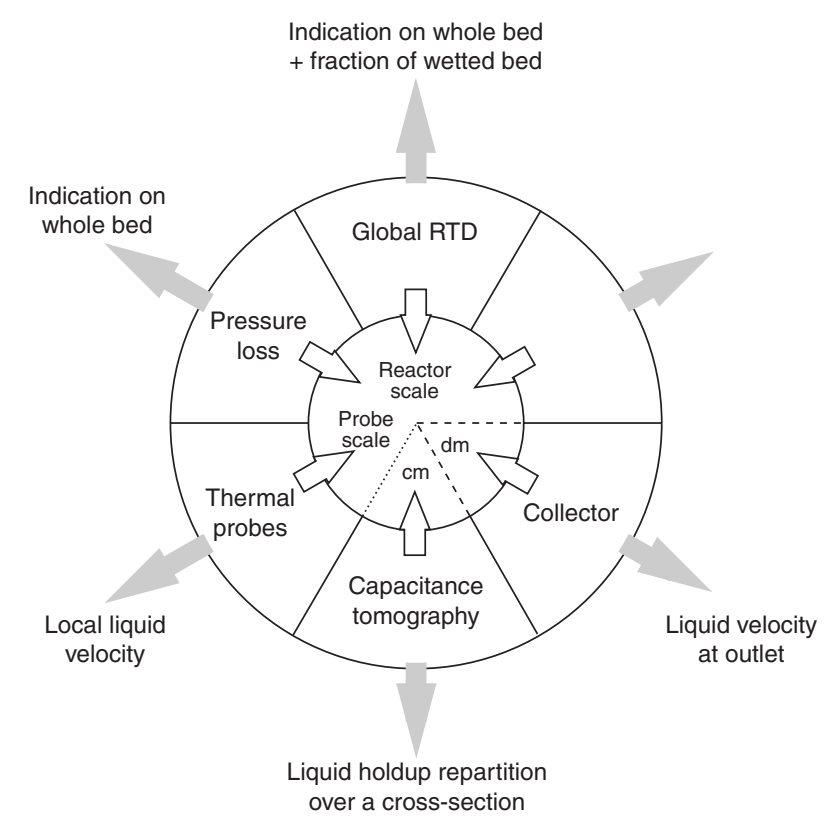

Figure 13

Overview of the different investigation techniques used in this work.

Some general rules on the influence of operating conditions on large-scale maldistribution can be established:

- the presence of gas tends to diminish maldistribution;

- increasing gas and liquid flow rates usually decreases maldistribution;

- a bad initial distribution will not correct itself totally. 
Similar rules are not yet available for smaller scale maldistribution. Further research is needed to define these scales.

In a commercial reactor:

- $\Delta P$ can indicate maldistribution, but other factors can interfere (bed attrition, coking) and no quantification is possible;

- RTD is working well and quantitative;

- thermal sensors are possible (Sapre et al., 1990) but too local and not realistic for every reactor;

- liquid collectors and tomography are impossible.

\section{REFERENCES}

Beck, M.S., Dyakowski, T. and Williams, R.A. (1997) Process Tomography-The State of the Art. Proc. Frontiers in Industrial Process Tomography II, Delft, The Netherlands, 357-362.

Bemer, G.G. and Zuiderweg, F.J. (1978) Radial Liquid Spread and Maldistribution in Packed Columns under Different Wetting Conditions. Chem. Eng. Sci., 33, 1637-1643.

Borda, M., Gabitto, J.F. and Lemcoff, N.O. (1987) Radial Liquid Distribution in a Trickle-Bed Reactor. Chem. Eng. Comm., 60, 243-252.

Chaouki, J.F., Larachi, F. and Dudukovic, M.P. (1997) Noninvasive Tomographic and Velocimetric Monitoring of Multiphase Flows. Ind. Eng. Chem. Res., 36, 4476-4503.

Herskowitz, M. and Smith, J.M. (1978) Liquid Distribution in Trickle-Bed Reactors. Part II: Tracer Studies. AIChE J., 24, 450454.

Hoek, P.J., Wessinlingh, J.A. and Zuiderweg, F.J. (1986) Small Scale and Large Scale Liquid Maldistribution in Packed Columns. Chem. Eng. Res. Des., 64, 431-449.

Kennedy, C.R. and Jaffe, S.B. (1986) Analysis of Tracer Experiments from Commercial-Scale Trickle-Bed Reactors. Chem. Eng. Sci., 41, 845-853.

Kouri, R.J. and Sohlo, J. (1996) Liquid and Gas Flow Patterns in Random Packing. Chem. Eng. J., 61, 95-105.

Lutran, P.G., Ng, K.M. and Delikat, E.P. (1991) Liquid Distribution in Trickle Beds. An Experimental Study using Computer-Assisted Tomography. Ind. Eng. Chem. Res., 30, 12701280.

Marcandelli, C., Wild, G., Lamine, A.S. and Bernard, J.R. (1999) Measurements of Local Particle-Fluid Heat Transfer Coefficient in Trickle-Bed Reactors. Chem. Eng. Sci., 54, 4997-5002.

Moller, L.B., Halken, C., Hansen, J.A. and Bartholdy, J. (1996) Liquid Gas Distribution in Trickle-Bed Reactors. Ind. Eng. Chem. Res., 35, 926-930.
Reinecke, N. (1996) Kapazitive Tomographie für transiente Mehrphasenströmungen. Thesis, Fakultät für Maschinenwesen, Hanover, Germany.

Reinecke, N. and Mewes, D. (1996a) Recent Developments and Industrial/Research Applications of Capacitance Tomography. Meas. Sci. Technol., 7, 233-246.

Reinecke, N. and Mewes, D. (1996b) Tomographic Imaging of Trickle-Bed Reactors. Chem. Eng. Sci., 51, 2131-2138.

Reinecke, N., Petritsch, G., Schmitz, D. and Mewes, D. (1998) Tomographic Measurement Techniques-Visualisation of Multiphase Flows. Chem. Eng. Technol., 21, 7-18.

Ross, L.D. (1965) Performance of Trickle-Bed Reactors. Chem. Eng. Prog., 61, 77-82.

Sapre, A.V., Anderson, D.H. and Krambeck, F.J. (1990) Heater Probe Technique to Measure Flow Maldistribution in Large Scale Reactors. Chem. Eng. Sci., 45, 2263-2268.

Saroha, A.K., Nigam, K.D.P., Saxena, A.K. and Kapoor, V.K. (1998) Liquid Distribution in Trickle-Bed Reactors. AIChE J., 44, 2044-2052.

Sylvester, N.D. and Pitayagulsarn, P. (1975) Radial Liquid Distribution in Cocurrent Two-Phase Downflow in Packed Beds. Can. J. Chem. Eng., 53, 599-605.

Toye, D., Crine, M., Marchot, P. and L'Homme, G. (1996) Modelling of the Multiphase Flow in Packed Beds by Computer Assisted X-ray Tomography. Meas. Sci. Technol., 7, 436-443.

Toye, D., Crine, M., Marchot, P. and L'Homme, G. (1997) Modelling of the Liquid Distribution in a Packed Column Based upon X-ray Tomography Images. Proc. Frontiers in Industrial Process Tomography II, Delft, The Netherlands, 337-342.

Trambouze, P.H., van Landeghem and Wauquier, J.P. (1984) Les réacteurs chimiques, Éd. Technip, Paris.

Vergel Hernandez, C.A. (1993) Les réacteurs catalytiques à lit fixe avec écoulement de gaz et de liquide. Comparaison sur les plans théoriques et expérimentaux du réacteur dans différents sens d'écoulement. PhD Thesis, Institut national polytechnique de Lorraine, Nancy, France.

Vergel, C., Euzen, J.P., Trambouze, P. and Wauquier, J.P. (1995) Two-Phase Flow Catalytic Reactor, Influence of Hydrodynamics on Selectivity. Chem. Eng. Sci., 50, 3303-3312.

Villermaux, J. and van Swaaij, W.P.M. (1969) Modèle représentatif de la distribution des temps de séjour dans un réacteur semi-infini à dispersion axiale avec des zones stagnantes. Application à l'écoulement ruisselant dans les colonnes d'anneaux Raschig. Chem. Eng. Sci., 24, 1097-1111.

Williams, R.A. and Xie, C.G. (1993) Tomographic Techniques for Characterising Particulate Processes. Part. Syst. Charact., 10, 252-261.

Yang, X.L., Euzen, J.P.and Wild, G. (1990) Residence Time Distribution of the Liquid in Gas-Liquid Cocurrent Upflow Fixed-Bed Reactors with Porous Particles. Chem. Eng. Sci., 45, 3311-3317. 